\section{A plant growth promoting rhi- zospheric Pseudomonas aerugi- nosa strain inhibits seed germination in Triticum aestivum (L) and Zea mays (L)}

\author{
Pankaj Tiwari, Jay Shankar Singh \\ Department of Environmental \\ Microbiology, Babasaheb Bhimrao \\ Ambedkar University, Lucknow, Uttar \\ Pradesh, India
}

\section{Abstract \\ Various rhizobacteria strains are isolat-} ed and tested worldwide for their plant growth promoting activities. A strain is said to be a plant growth promoter if it has the ability to influence plant growth directly or indirectly. Though the main focus has always been to realize the plant growth promoting traits of rhizobacteria and use them as biofertilizers, but the disadvantages or deleterious effects of such plant growth promoting rhizobacteria (PGPR) if any have also been ignored to a greater extent. The present study deals with the characterization of both promoting as well as deleterious activities of an isolated strain of Pseudomonas aeruginosa on plants. The bacterium was isolated from the soil of the college campus of Babasaheb Bhimrao Ambedkar University, Lucknow, Uttar Pradesh and was characterized as $P$. aeruginosa by various positive biochemical tests such as oxidase, catalase, citrate tests and confirmed by MALDI-TOF-MS. Its growth as well as IAA producing ability at different salt $(\mathrm{NaCl})$ concentrations was tested. Tests examining $\mathrm{HCN}$, Ammonia and siderophore production, flocculation ability, phosphate and zinc solubilization by the strain were carried out. Its anti-microbial property was tested against three phytopathogenic fungi: Fusarium solani, Aspergillus niger and Curvularia lunata and two bacterial strains- Klebsiella pneumoniae and E. coli. Its effect over seed germination of Triticum aestivum and Zea mays was inspected in plates as well as in pots. The strain showed a great potential as a plant growth promoter growing up to $10 \% \mathrm{NaCl}$ concentration and producing considerable amount of IAA upto $8 \% \mathrm{NaCl}$ concentration. It showed antagonistic nature against the three phytopathogenic fungi, solubilized phosphate and produced siderophore and $\mathrm{NH}_{3}$. Though supernatant of the bacterial culture did not show any deleterious effect over seed (of the test plants $T$. aestivum and Z. mays) germination but the seeds inoculated with the strain itself, failed to germinate. The seed turned dormant and grew a pale brown color showing bacterial growth over it. Thus it maybe concluded that the isolated strain of $P$. aeruginosa has abilities to both promote and at the same time inhibit plant growth (by inhibiting seed germination).

\section{Introduction}

$P$. aeruginosa has long been under human concern. Its plant growth promoting characteristics have always been debatable, a major cause being its opportunistic pathogenic nature causing a wide array of hospital born infections in humans. ${ }^{1}$ It is amongst the most successful organisms that have been able to modify themselves to survive the changing environment; whether be it saline or acidic conditions or the antibiotic menace. Today $P$. aeruginosa is one of the most potent multiple drug resistant bacterium which has been able to resist an innumerable antibiotics. ${ }^{2}$ This is what makes it interesting for the researchers to study on this particular unpredictable bacterium. Plant growth promoting rhizobacteria are a group of bacteria that reside inside the rhizosphere and help in plant development. ${ }^{3}$ Rhizosphere is that part of the soil which is strictly governed by the roots of the plant. ${ }^{4}$ These plant growth promoters may help the plant directly or indirectly. Direct methods include phytohormone production such as Indole Acetic Acid (IAA), Gibberellic Acid (GA) etc., ammonia production (as $\mathrm{N}$ source), atmospheric nitrogen fixation, siderophore production (for iron chelation), zinc and phosphate solubilization and providing tolerance against unfavorable conditions (high salinity) etc. ${ }^{5}$ Indirect methods of plant growth inducing methods involve anti-phytopathogenic ability by producing secondary metabolites such as antibiotics or hydrogen cyanide that restrict the growth of various fungal as well as bacterial species that produce deleterious effects over plant. ${ }^{5}$

Seeds are the most important part of an angiosperm's lifecycle. Weather the plant's geneline will continue or not depends on its seeds' ability to germinate. There are various factors that regulate seed germination such as temperature, light, moisture, $\mathrm{pH}$, etc. ${ }^{6,7}$ Some rhizobacterial species may inhibit seed germination completely or reduce its ability to germinate. ${ }^{8}$ Hence if a microorganism shows an array of plant growth promoting characters in vitro but hinders seed germination it is contradictory to consider it as a plant growth promoter. Also these microorganisms may have an
Correspondence: Jay Shankar Singh, Department of Environmental Microbiology, Babasaheb Bhimrao Ambedkar University, Lucknow, Uttar Pradesh, 226025 India.

E-mail: jayshankar_1@yahoo.co.in

Key words: Antagonism; MALDI-TOF MS; PGPR; Phytohormones; Rhizobacteria

Acknowledgments: The authors thank the Head, Department of Environmental Microbiology, Babasaheb Bhimrao Ambedkar University for providing all the necessary facilities for this work

Contributions: PT, generated the idea, designed the study, performed the experiments and wrote the manuscript. JSS helped in conducting the experiments, evaluated data and edited the manuscript.

Conflict of interest: the authors declare no potential conflict of interest.

Received for publication: 29 May 2017

Accepted for publication: 5 June 2017.

This work is licensed under a Creative Commons Attribution NonCommercial 4.0 License (CC BY-NC 4.0).

(C) Copyright P. Tiwari and J.S. Singh, 2017 Licensee PAGEPress, Italy

Microbiology Research 2017; 8:7233

doi:10.4081/mr.2017.7233

important role in natural as well as artificial environment (agricultural fields). Therefore it is necessary to carry out experiments to understand the nature of such bacterial strains.

\section{Materials and Methods}

\section{Isolation}

The soil sample was serially diluted up to $10^{-4}$ dilutions and filtered in test tubes. $0.25 \mathrm{~mL}$ of the filtered solution was spread using an L-shaped spreader on nutrient agar media containing per litre of doubled distilled water, $5.0 \mathrm{~g}$ peptone, $1.5 \mathrm{~g}$ yeast extract, $1.5 \mathrm{~g}$ beef extract, $5.0 \mathrm{~g} \mathrm{NaCl}$ and $18 \mathrm{~g}$ agar, $\mathrm{pH}$ was maintained at 7.2 and plates were incubated at $28.5^{\circ} \mathrm{C}$ for $72 \mathrm{hrs}$.

\section{Selective media for Pseudomonas aeruginosa}

The obtained pure colonies were transferred to cetrimide agar media containing per litre of distilled water, ${ }^{9} 20 \mathrm{~g}$ enzymatic digest of gelatin, $1.4 \mathrm{~g} \mathrm{MgCl}_{2}, 10 \mathrm{~g} \mathrm{KCl}, 0.3$ $\mathrm{g}$ cetrimide (Cetrimethylammonium Bromide), $10 \mathrm{~mL}$ glycerol and $13.6 \mathrm{~g}$ 
agar. Plates were incubated for $48 \mathrm{hrs}$ at $28.5^{\circ} \mathrm{C}$. Colonies identical to $P$. aeruginosa showed bluish green fluorescence under UV light (254 nm).

\section{Characterization}

\section{Gram staining and microscopy}

The protocol was carried out as stated by Bartholomew and Mittwer (1952). ${ }^{10}$ Pinch of colonies were taken on a slide and a thin smear was formed by adding a drop of distilled water. Smear was air dried and heat fixed. Slide was flooded with crystal violet, kept for $1 \mathrm{~min}$ and was gently washed in an indirect stream of tap water. A drop of Gram's iodine was applied as a mordant for $1 \mathrm{~min}$. and the slide was again gently washed. Alcoholacetone decolorizer was poured drop by drop on the inclined slide until the decolorizing agent ran clear. The slide was counter stained with safranin for $45 \mathrm{sec}$ onds, washed under an indirect stream and excess water was absorbed on a tissue paper. Violet to purple color colony are said to be gram positive whereas pinkish-red colony show gram negative test. Cell morphology was observed under oil immersion $(100 \times)$ of a bright field compound microscope.

\section{Biochemical assay Catalase test}

A loop full of cells from a $24 \mathrm{hrs}$ old bacterial culture was transferred to a slide and a drop of $3 \%$ hydrogen peroxide was added. Occurrence of bubbles indicated a positive test for catalase production by the bacteria. $^{11}$

\section{Oxidase test}

The test was performed as stated by Isenberg (2004). ${ }^{12}$ Bacterial cells were cultivated in tripticase soy agar containing per litre of doubled distilled $\mathrm{H}_{2} \mathrm{O}, 17 \mathrm{~g}$ tryptone, $3 \mathrm{~g}$ soytone, $2.5 \mathrm{~g}$ dextrose, $5 \mathrm{~g} \mathrm{NaCl}, 2.5 \mathrm{~g}$ $\mathrm{K}_{2} \mathrm{HPO}_{2}, 15 \mathrm{~g}$ agar, $\mathrm{pH} 7.2$ and incubated for $24 \mathrm{hrs}$ at $28.5^{\circ} \mathrm{C}$. Pinch of colonies were transferred to a sterile filter paper aseptically with a glass rod and 2-3 drops of N, N-dimethyl-pphenylenediamine (DMPD) was added. A color change from violet to purple indicated a positive oxidase test confirming cytochrome oxidase production by the bacteria.

\section{Citrate test}

Simmon's citrate agar containing per litre of distilled $\mathrm{H}_{2} \mathrm{O}, 5 \mathrm{~g} \mathrm{NaCl}, 2 \mathrm{~g}$ sodium citrate, $1 \mathrm{~g}$ ammonium dihydrogen phosphate, $1 \mathrm{~g}$ dipotassium phosphate, $0.2 \mathrm{~g}$ magnesium sulphate, $0.08 \mathrm{~g}$ bromothymol blue, $15 \mathrm{~g}$ agar; was prepared, autoclaved and poured in plates. The media was spot inoculated and incubated at $28.5^{\circ} \mathrm{C}$ for 24 hrs. Color of the media changed from green to blue indicating a positive test and bacterial capability to utilize citrate as carbon source by producing the enzyme citrate permease. ${ }^{13}$

\section{Urease test}

Christensen's urea agar containing per litre distilled $\mathrm{H}_{2} \mathrm{O}, 20 \mathrm{~g}$ urea, $5 \mathrm{~g} \mathrm{NaCl}, 2 \mathrm{~g}$ monopotassium phosphate, $1 \mathrm{~g}$ peptone, $1 \mathrm{~g}$ dextrose, $18 \mathrm{~g}$ agar, and $0.012 \mathrm{~g}$ phenol red; was prepared and sterilized. The media was poured in test tubes and slants were prepared. The slant was streaked with the bacterial isolate and incubated at $28.5^{\circ} \mathrm{C}$ for 48 hrs. Development of bright pink color indicated urease positive. ${ }^{14}$

\section{MALDI-TOF mass spectrometry}

Matrix Assisted Laser Desorption Ionization Time-of-Flight Mass Spectrometry (MALDI- TOF MS) is one of the most famous modern approaches used in bacterial cell identification. The procedure was followed as stated by Etienne et al. ${ }^{15}$ Condensed biopolymer molecules were converted into intact, ionized molecules in the gas phase. Ions were then separated based on their molecular mass $(\mathrm{m})$, the charge $(\mathrm{z})$, the ratio mass/charge $(\mathrm{m} / \mathrm{z})$, and the relative intensity of the signal. Initially crystals between the sample and an organic matrix (co-crystallization) were formed. The sample was then spotted on MALDI-TOF sample target with an appropriate matrix (Sinapinic Acid) and was allowed to air dry at room temperature. Then, the plate was inserted into the MS; the dried matrix was bombarded with a laser to create gas phase ions that were then pulsed into a flight tube. Generally only a singly ionized species having a single charge is produced. The species of interest were identified by their mass/charge ratio. The $\mathrm{m} / \mathrm{z}$ value was obtained from the centroid of the peak. Among the compounds detected in the spectrum, some peaks (molecular masses) are specific to genus, species and sometime to subspecies. Matrix is surely the most important part of this process to acquire a reliable result with least variance. Thus keeping this in mind Sinapinic Acid was used as the matrix for the identification of the isolate.

\section{Growth at various salt concentra- tions}

Nutrient broth containing per litre distilled $\mathrm{H}_{2} \mathrm{O}, 5 \mathrm{~g}$ peptone, $1.5 \mathrm{~g}$ yeast extract, $1.5 \mathrm{~g}$ beef extract was prepared and $4 \mathrm{~mL}$ of it was poured in $10 \mathrm{~mL}$ sterile vials each. $\mathrm{NaCl}$ was added from $1 \%$ to $10 \%$ in set of 24 vials each (240 vials), another set of 24 vials lacked $\mathrm{NaCl}$ for $0 \% \mathrm{NaCl}$ con- centration. All the vials were marked according to their salt concentrations. The vials containing media were autoclaved at $121^{\circ} \mathrm{C}$ at $15 \mathrm{lbs}$ for 15 minutes.

Each vial was inoculated with $75 \mu \mathrm{L}$ of $24 \mathrm{hrs}$ old bacterial culture prepared in nutrient broth and kept in incubator at $28.5^{\circ} \mathrm{C}$. Optical density of each triplicate sample was noted using UV-visible spectrophotometer at different time intervals: 0 hr, 3 hrs, 6 hrs, 9 hrs, 12 hrs, 15 hrs, 18 hrs, $21 \mathrm{hrs}$ and $24 \mathrm{hrs}$. Growth curves under various salt concentrations were monitored.

\section{Antibiotic sensitivity}

Antibiotic sensitivity was tested by disk diffusion method against 6 different antibiotics namely Amikacin $10 \mathrm{mcg}$ (AK10), Bacitracin (B), Clindamycin 10 mcg (CD10), Gentamycin $120 \mathrm{mcg}$ (HLG120), Chloramphenicol $30 \mathrm{mcg}$ (C30) and Ciprofloxacin 5 mcg (CIP5). ${ }^{16}$ Mueller Hinton agar media containing per litre distilled $\mathrm{H}_{2} \mathrm{O}, 2 \mathrm{~g}$ beef extract, $17.5 \mathrm{~g}$ acid hydrolysate of casein, $1.5 \mathrm{~g}$ starch, and $17 \mathrm{~g}$ agar was prepared, sterilized and plated. 24 hrs old bacterial cultures were spread on the media and antibiotic discs were placed (3 in one plate). The plates were incubated for 48 hrs at $28.5^{\circ} \mathrm{C}$. Zones around the antibiotic disk indicated bacterial susceptibility whereas no zone indicated bacterial resistance.

\section{Flocculation test}

Nutrient broth was prepared and sterilized in a conical flask. It was inoculated with a freshly prepared bacterial culture and incubated at $28.5^{\circ} \mathrm{C}$ in a normal incubator for $72 \mathrm{hrs}$. It was made sure that the conical flask is undisturbed. Floating bacterial clumps indicated bacterial ability to flocculate.

\section{In vitro assays for PGPR abilities Phosphate solubilization}

The method stated by Pikovskaya was followed. ${ }^{17}$ Pikovskaya Agar medium containing per litre distilled $\mathrm{HO}, 10 \mathrm{~g}$ glucose, $5 \mathrm{~g} \mathrm{Ca}_{3}\left(\mathrm{PO}_{4}\right)_{2}, 0.5 \mathrm{~g}\left(\mathrm{NH}_{4}\right)_{2} \mathrm{SO}_{4}, 0.2 \mathrm{~g} \mathrm{NaCl}$, $0.1 \mathrm{~g} \mathrm{MgSO}_{4} 7 \mathrm{H}_{2} \mathrm{O}, 0.1 \mathrm{~g} \mathrm{KCl}, 0.5 \mathrm{~g}$ yeast extract, $0.002 \mathrm{~g} \mathrm{MnSO}_{4} \mathrm{H}_{2} \mathrm{O}, 0.002 \mathrm{~g}$ $\mathrm{FeSO}_{4} 7 \mathrm{H}_{2} \mathrm{O}, 18 \mathrm{~g}$ agar was prepared and poured in plates after sterilization. The media was spot inoculated in the center and incubated at $28.5^{\circ} \mathrm{C}$ for $48 \mathrm{hrs}$. A transparent zone around the inoculums showed phosphate solubilizing ability of the strain.

\section{Zinc solubilization}

Nutrient agar medium supplied with $0.1 \%$ zinc oxide was prepared, sterilized and poured in plates. It was spot inoculated in the center using an inoculation loop and 
incubated for $28.5^{\circ} \mathrm{C}$ for $24 \mathrm{hrs}$. A transparent zone around the inoculum showed zinc solubilizing ability of the strain. ${ }^{18}$

\section{$\mathrm{NH}_{3}$ production}

$0.1 \mathrm{~mL}$ bacterial culture was added to $10 \mathrm{~mL}$ sterilized peptone water in a conical flask, and incubated for $28.5^{\circ} \mathrm{C}$ for $48 \mathrm{hrs}$. $0.5 \mathrm{~mL}$ Nessler's reagent was added to it. Development of yellowish brown color indicated ammonia production. ${ }^{19}$

\section{HCN production}

Production of $\mathrm{HCN}$ was tested as stated by Castric (1975). ${ }^{20} \mathrm{HCN}$ induction media - Kings media $\mathrm{B}$ base containing per litre distilled $\mathrm{H}_{2} \mathrm{O}, 20$ g peptone, $1.5 \mathrm{~g}$ dipotassium hydrogen phosphate, $1.5 \mathrm{~g}$ magnesium sulphate heptahydrate, $10 \mathrm{~g} \mathrm{NaCl}, 15 \mathrm{~mL}$ glycerol, 20 g agar; supplemented with 4.4 $\mathrm{g}$ glycine was prepared, sterilized and plated. The media was streaked with bacterial culture and a Whatman filter paper no. 1 soaked in $2 \%$ sodium carbonate in $0.5 \%$ picric acid solution was placed inside the top of the plate. Plates were sealed with parafilm and incubated at $28.5^{\circ} \mathrm{C}$ for 72 hrs. The change in color of the filter paper from light yellow to reddish brown indicated HCN production. The filter paper is soaked in $10 \mathrm{~mL}$ doubled distilled $\mathrm{H}_{2} \mathrm{O}$ and optical density of this solution is taken at $540 \mathrm{~nm}$. The control plate's filter paper (not inoculated, hence no change in color) is also soaked in $10 \mathrm{~mL}$ distilled $\mathrm{H}_{2} \mathrm{O}$ and the solution is used as blank.

\section{Siderophore production}

Chrome azurol $\mathrm{S}$ agar was prepared by mixing per $990 \mathrm{~mL}$ distilled $\mathrm{H}_{2} \mathrm{O}, 60.5 \mathrm{mg}$ chrome azurol S, $72.9 \mathrm{mg}$ hexadecyltrimethyl ammonium bromide, $10 \mathrm{~mL}$ of $1 \mathrm{mM} \mathrm{FeCl}_{3} .6 \mathrm{H}_{2} \mathrm{O}$ solution prepared in 10 $\mathrm{mM} \mathrm{HCl}, 42.23 \mathrm{~g}$ Kings media B base; Media was autoclaved and poured in plates for solidification. It was spot inoculated with 24 hrs old culture of test organism (10 $\mu \mathrm{L})$ and incubated at $28.5^{\circ} \mathrm{C}$ for $72 \mathrm{hrs}$. Development of yellow orange halo around the bacterial growth was considered positive for siderophore production. ${ }^{21}$

\section{Production of indole 3 -acetic acid at various salt concentrations Qualitative test}

Protocol stated by Ehmann (1977) was followed. ${ }^{22}$ Luria-Bertani broth containing per litre distilled $\mathrm{H}_{2} \mathrm{O}, 10 \mathrm{~g}$ tryptone, $5 \mathrm{~g}$ yeast extract; supplied with $5 \mathrm{mg} / \mathrm{mL}$ tryptophan was prepared and poured into vials $(2 \mathrm{~mL}$ each). Salt $(\mathrm{NaCl})$ was added from $1 \%$ to $10 \%$ in different vials in triplicates. Another set of 3 vials were left for $0 \%$ salt concentration. Vials were marked according to their salt con- centration and autoclaved. Each vial was inoculated with $0.1 \% 24 \mathrm{hrs}$ old bacterial cultures and incubated at $28.5^{\circ} \mathrm{C}$ for $72 \mathrm{hrs}$. The culture was centrifuged at $8,000 \mathrm{rpm}$ for $10 \mathrm{~min}$ and the supernatant was recollected in the respective vials. $2 \mathrm{~mL}$ Salkowski reagent containing per litre distilled $\mathrm{H}_{2} \mathrm{O}, 600 \mathrm{~mL} \mathrm{H}_{2} \mathrm{SO}_{4}$, $20 \mathrm{~mL} \mathrm{FeCl}_{3}$ was added to each supernatant. Color change to reddish pink indicated positive test for IAA production.

\section{Quantitative test}

Optical density of the above reddish pink solution was taken at $530 \mathrm{~nm}$ with the help of UV-VIS Spectrophotometer. ${ }^{23}$ Concentration of IAA produced by the culture at various salt concentrations was measured using standard graph of IAA obtained in the range of $10-100 \mu \mathrm{g} / \mathrm{mL}$.

\section{Confirmatory test}

72 hrs grown cultures (in LB-Try media supplemented with various $\mathrm{NaCl}$ concentrations) were centrifuged at 8,000 rpm for 10 minutes. The supernatants were collected and acidified with $\mathrm{HCl}(\mathrm{pH} 2.8)$. It was extracted adding ethyl acetate of equal volume. The extracts were air dried, recollected in ethanol and analyzed using thin layer chromatography (TLC) to confirm the presence of IAA. ${ }^{22}$

\section{Antimicrobial assay \\ Antibacterial assay}

Well diffusion method was used in which 24 hrs old cultures of Klebsiella sp. and $E$. coli (in nutrient broth) was spread separately on plates containing nutrient agar media. ${ }^{24} 8 \mathrm{~mm}$ wells were made in the center of the plates and were filled with $200 \mu \mathrm{L}$ of $P$. aeruginosa strain. It was incubated for $72 \mathrm{hrs}$ at $28.5^{\circ} \mathrm{C}$. Nutrient broth was taken as a negative control whereas the antibiotic Ceftazidime (100 $\mu \mathrm{g} / \mathrm{L}$ ) was used as a positive control. Development of clear zones around wells indicated positive antagonistic activity of the bacterial strain.

\section{Antifungal assay}

Potato dextrose agar (PDA) media containing per litre distilled water, $200 \mathrm{~g}$ potato infusion, $20 \mathrm{~g}$ dextrose, and $20 \mathrm{~g}$ agar powder was prepared, autoclaved and poured in plates. Further 3 different modified dual culture methods were used to examine the antifungal property of the isolated strain.

\section{Single streak method}

A straight line streak of bacterial strain was made at one corner of the plate containing PDA media using inoculation loop. An $8 \mathrm{~mm}$ fungal colony (cut from a pure fungal culture) was placed at the extreme opposite corner.

\section{Double streak method}

Two straight line streak of bacterial strain were made at extreme opposite corners of the plate and $8 \mathrm{~mm}$ fungal colony was placed in the center.

\section{Spread method}

The plates were spread with $0.1 \mathrm{~mL}$ bacterial culture and $8 \mathrm{~mm}$ fungal colony was placed at the center of the plate.

The plates were then incubated at $28.5^{\circ} \mathrm{C}$ for 7 days. Control plates were not inoculated with bacterial culture. Inhibition of fungal growth was calculated using the formula: growth inhibition $=($ control - test ( control) $\times 100$ as proposed by Skidmore and Dickinson (1976). ${ }^{25}$ Here control and test signifies the fungal growth (diameter) in control and test plates respectively. The above set up was tested with 3 different sp. of fungi namely Fusarium solani, Aspergillus niger and Curvularia lunata.

\section{Bacterial effect on seed germination In vitro assay}

Seeds were prepared according to the procedure stated by Lubna et al. ${ }^{26}$ Seeds of Z. mays and T. aestivum were surface sterilized with $0.1 \% \mathrm{HgCl}_{2}$ for 2 minutes and washed with sterile water. Seeds were constantly shaken with 24 hrs old bacterial culture (in nutrient broth) until a thin layer of bacteria developed around seeds. Carboxymethyl cellulose (CMC) was used as a binding agent. Seeds were air dried and placed in plates containing soft agar media (75 g agar per litre distilled $\mathrm{H}_{2} \mathrm{O}$ ). Control plates were prepared with sterilized seeds without bacterial inoculation. The plates of Zea mays and $T$. aestivum were kept at $20 \pm 2^{\circ} \mathrm{C}$ and $28 \pm 2^{\circ} \mathrm{C}$ respectively.

\section{Effect of antibiotics over seed germina- tion inoculated with $P$. aeruginosa}

Six antibiotics namely Amikacin (AK), Bacitracin (B), Clindamycin (CD), Gentamycin (HLG), Chloramphenicol (C) and Ciprofloxacin (CIP) in concentration of $2000 \mu \mathrm{g} / \mathrm{L}$ were added separately to plates containing soft agar media. Seeds were sterilized and inoculated with the isolated bacterial culture as mentioned above. Control plates were prepared with sterilized seeds without bacterial inoculation. The plates of $Z$. mays and T. aestivum are kept at $20 \pm 2^{\circ} \mathrm{C}$ and $28 \pm 2^{\circ} \mathrm{C}$ respectively.

\section{Pot experiment}

Soil was collected and autoclaved 3 times to kill any possible microbial life. Sterilized pots were filled with the soil. Set of test pots 
were added with $1 \mathrm{~mL} 24$ hrs old bacterial culture (in nutrient broth) and control pots were left un-inoculated. The sterilized seeds were sown in both test pots and control pots. The pots were kept at favorable temperature (mentioned above) and mentored for a weak to observe germination.

\section{Results}

\section{Characterization and identification}

All the biochemical and morphological characteristics of the isolated strain strongly indicated its similarity with that of $P$. aeruginosa (Table 1). Further MALDI-TOF MS (Figure 1) confirmed it to be P. aeruginosa at a confidence value of 89.2.

The isolated strain was resistant to 5 of the 6 tested antibiotics, being sensitive only to Ciprofloxacin (Table 2).

The bacterial strain was found to thrive and even grow up to $1.71 \mathrm{~mol}$ $(10 \%)$ salt $(\mathrm{NaCl})$ concentrations. Mean of the triplicates was calculated and growth curves were drawn (Figure 2). The growth curves showed a gradual decline in bacterial growth rate as the salt concentration rose. Also the log phase became dilatory with increase in salt concentration.

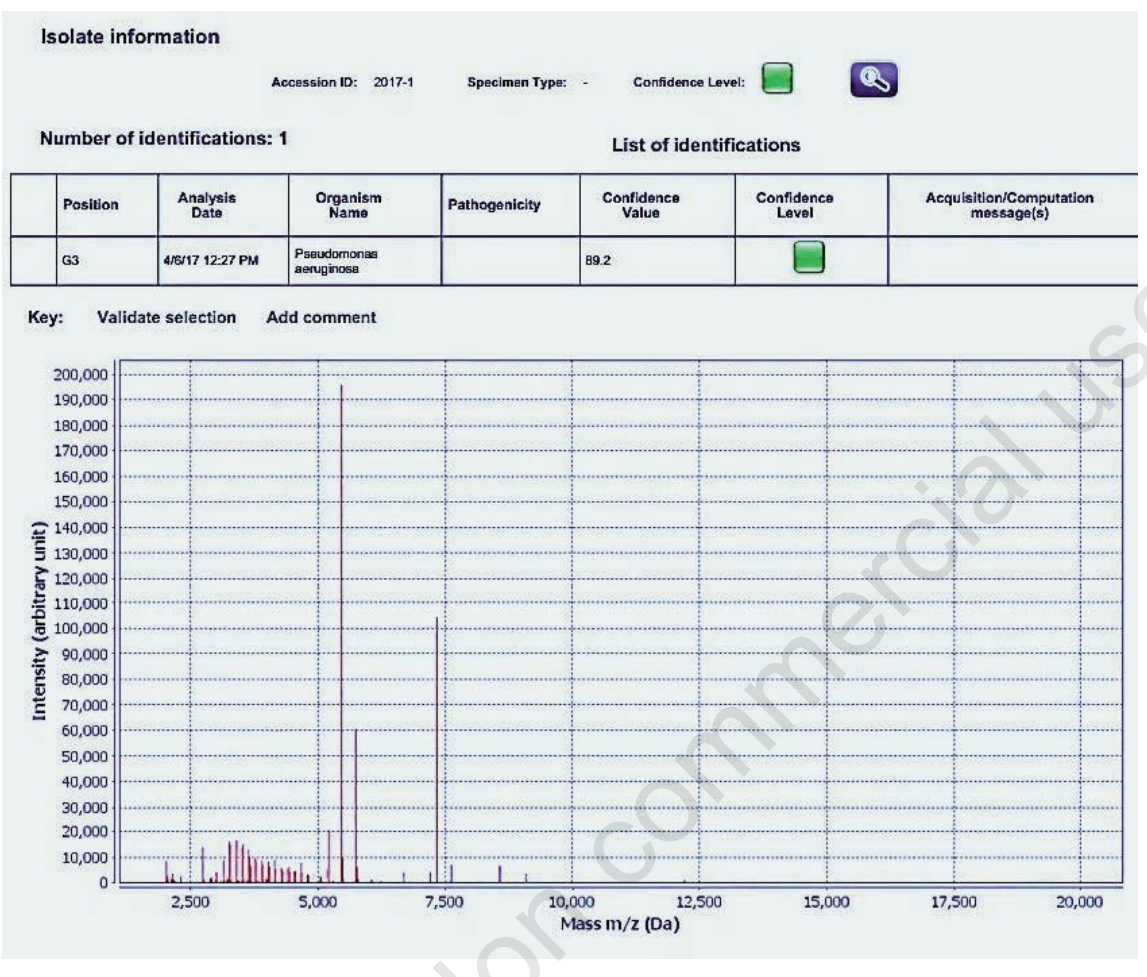

Figure 1. MALDI-TOF analysis report.

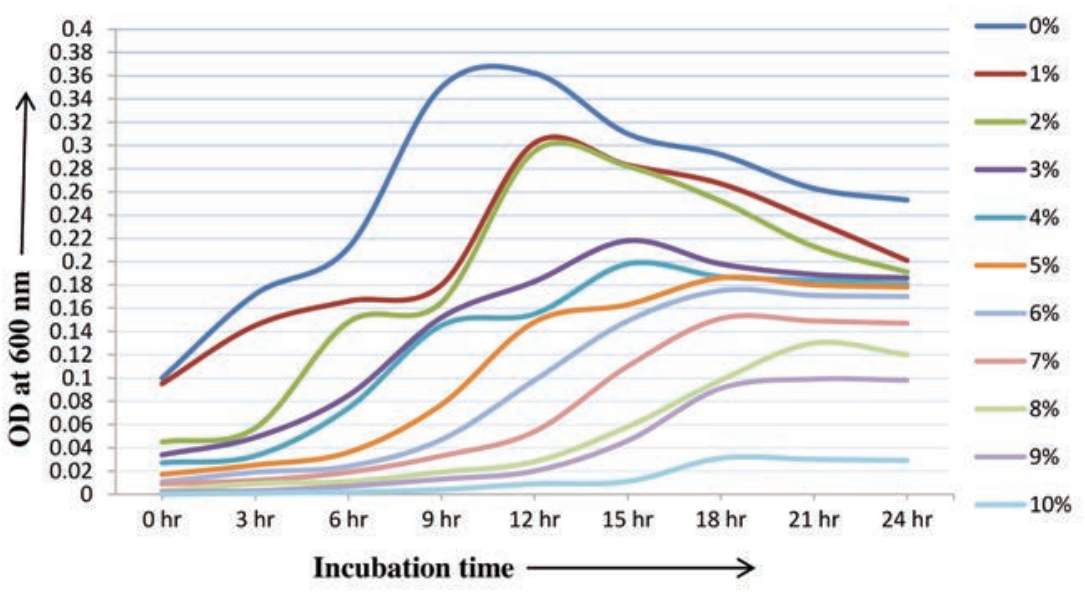

Figure 2. Growth curves showing bacterial growth (Optical density) at different salt concentrations at different time intervals.

\section{Plant growth promoting characteristics}

A well-developed zone around the inoculum in Pikovskaya medium confirmed the bacterial ability to solubilize phosphate (Figure 3A). Diameter of the transparent zone (indicating $\mathrm{P}$ solubilization) after 24 hrs, $48 \mathrm{hrs}$ and $72 \mathrm{hrs}$ was measured to be $1.1 \pm 0.1 \mathrm{~cm}, 1.9 \pm 0.1 \mathrm{~cm}$, and $3.3 \pm 0.2 \mathrm{~cm}$ respectively. An orange brown color developed on addition of Nessler's reagent to the $24 \mathrm{hrs}$ old bacterial culture in peptone water which indicated the bacterial ability to produce ammonia. After $72 \mathrm{hrs}$ incubation the filter paper soaked with picric acid solution turned brownish red confirming the production of $\mathrm{HCN}$ by the isolated strain. The optical density for the solution (test filter paper soaked in $10 \mathrm{~mL}$ distilled $\mathrm{H}_{2} \mathrm{O}$ ) was found to be $0.743 \pm 0.01$. The isolated strain of $P$. aeruginosa was highly able to produce siderophore as it developed around a yellow orange halo in chrome azurol $\mathrm{S}$ agar medium (Figure 3B).

\section{IAA producing ability at various salt concentrations}

Appearance of pink color on addition of Salkowski reagent up to $8 \% \mathrm{NaCl}$ concentration indicated the production of IAA

Table 1. General characteristics of the isolated strain.

\begin{tabular}{lc} 
Characters studied & Observations \\
Colony morphology & \\
Pigmentation & Fluorescent green \\
Appearance & Sticky, mucilaginous \\
Odor & Fruity \\
Exopolysaccharide secretion & Present \\
Ability to flocculate & Present \\
Cell morphology & \\
Shape & Rods \\
Size & Small \\
Gram staining & Negative \\
Motility & Positive \\
\hline Biochemical tests & \\
Catalase & Positive \\
Oxidase & Positive \\
Citrate & Positive \\
Cetrimide & Positive \\
\hline
\end{tabular}

Table 2. Antibiotic resistance.

\begin{tabular}{ll}
\hline Antibiotic resistance & Results \\
Ciprofloxacin 5 mcg (CIP5) & Negative \\
Amikacin 10 mcg (AK10) & Positive \\
\hline Bacitracin (B) & Positive \\
Clindamycin 10 mcg (CD10) & Positive \\
\hline Gentamycin 120 mcg (HLG120) & Positive \\
Chloramphenicol 30 mcg (C30) & Positive \\
\hline
\end{tabular}


by the bacteria when supplemented with tryptophan (Figure 4). Furthermore it was observed that the $\mathrm{R}_{\mathrm{f}}$ value for both stan-
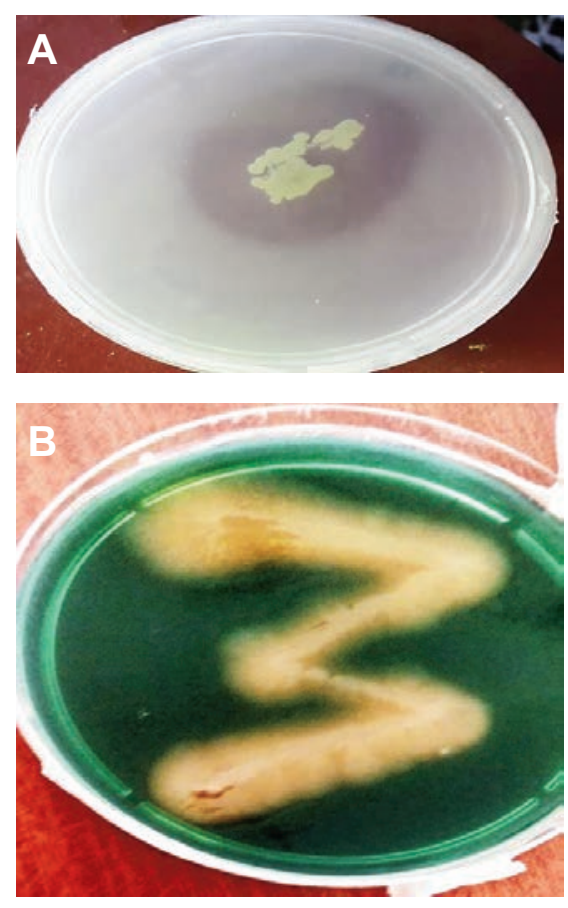

Figure 3. A) P. solubilization; B) Siderophore production. dard IAA and the compound produced by the bacterial strain was similar (0.92) confirming their homology. It was also recorded that with increase in salt concentration up to $6 \%$, there was no major fall in IAA production by the bacteria but it abruptly descended above that making it negligible above $8 \%$ salt concentration. The bacterial strain was able to produce $13.2 \pm 0.20 \mu \mathrm{g} / \mathrm{mL}$ of IAA when supplemented with $5 \mathrm{mg} / \mathrm{mL}$ Tryptophan as determined from the standard IAA graph.

\section{Antagonistic effect}

The isolated strain showed antagonistic effect against the 5 tested microbial cultures namely Klebsiella sp., E. coli, Fusarium solani, Aspergillus niger and Curvularia lunata. It was observed that as the microbes came in contact with the isolate they stopped growing.

\section{Antibacterial nature}

The isolated bacterial strain inhibited the growth of both the test bacteria. The diameter of growth inhibition the zones were calculated and mean values were considered from the triplicate set. The diameter of inhibition zone against Klebsiella sp. was noted to be greater $(27 \pm 0.75)$ in comparison to E. coli $(19 \pm 1.0$ $\mathrm{mm}$ ) (Table 3).

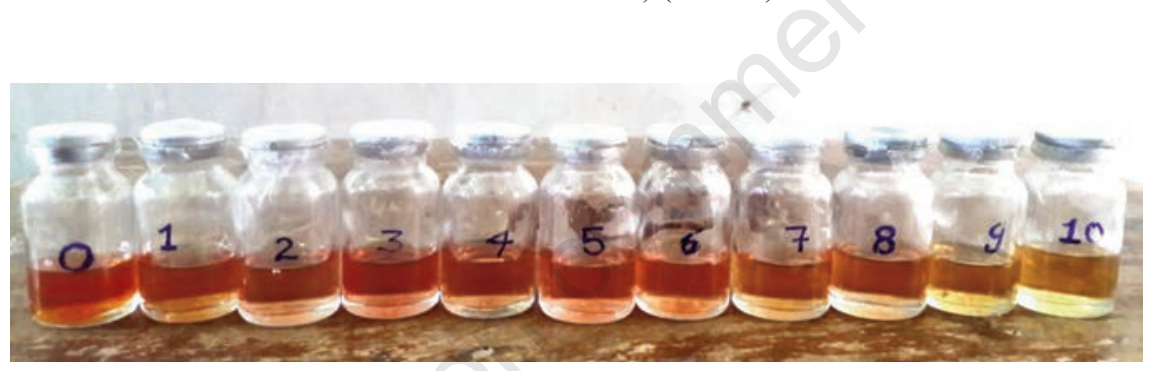

Figure 4. IAA production up to $8 \% \mathrm{NaCl}$ concentration.
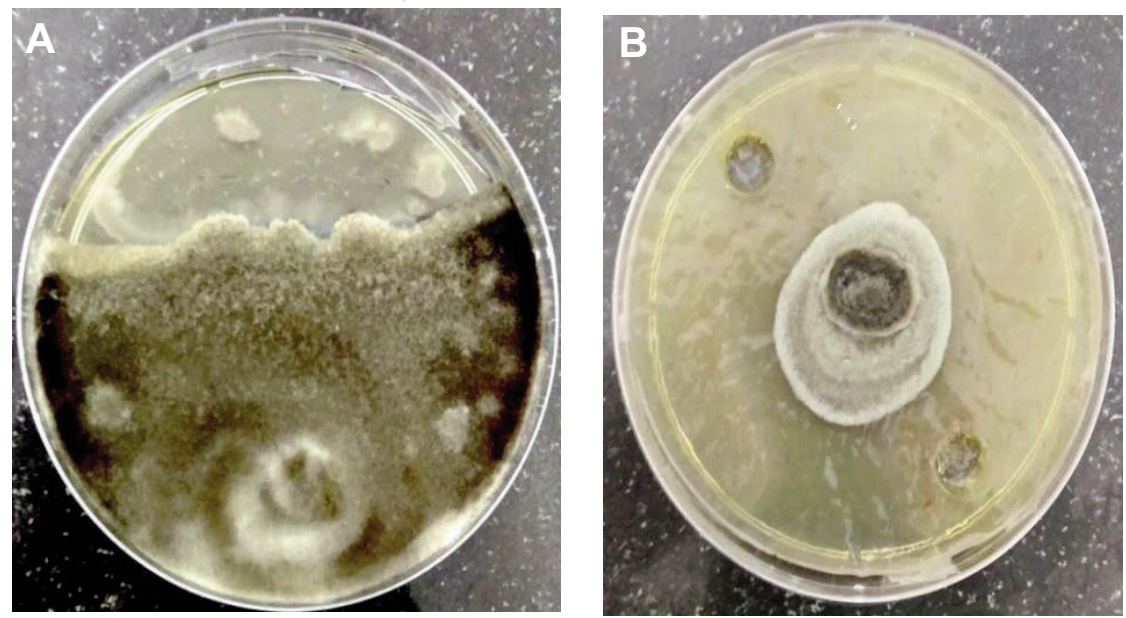

Figure 5. Bacterial antagonism against Curvularia lunata: A) single streak method, B) double streak method, C) spread method.

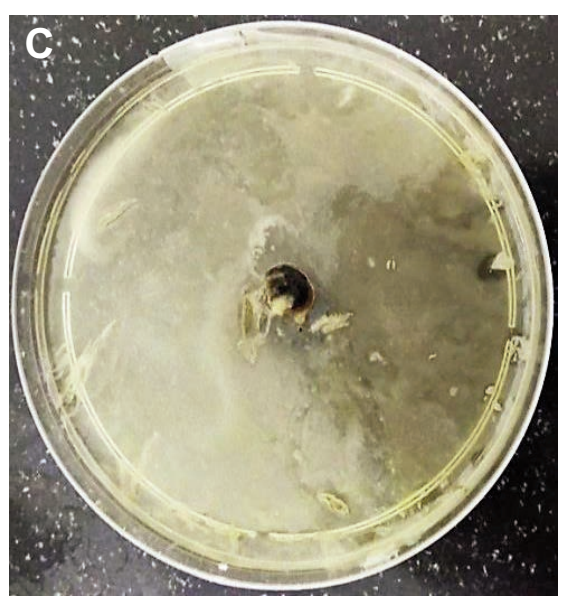

\section{Antifungal nature}

The bacterial strain was able to inhibit fungal growth up to $100 \%$ when spread onto the culture media. The effectiveness increased in the order: single streak method $<$ double streak method $<$ spread method (Figures 5 and 6). The average percentage growth inhibition by the bacterial strain was calculated from the triplicate (Tables 4 and 5).

\section{Deleterious effects over seeds}

Though the control seeds of T. aestivum and Zea mays that germinated within 24 and $72 \mathrm{hrs}$ respectively in soft agar media, it was observed that the test seeds (inoculated with the bacterial strain) of both the plant species did not germinate at all (Figure 7). The seeds became soft, covered with a thick, light brown colored bio-film of the bacterial strain (Figure 7B,C) The pot experiment gave the same result with no seed germination in the test pots at all (Figure 7D). Hence it can be concluded that the seed germination was hindered by the bacterial strain of $P$. aeruginosa. Also when media was supplemented with the 6 antibiotics namely Amikacin (AK), Bacitracin (B), Clindamycin (CD), Gentamycin (HLG), Chloramphenicol (C) and Ciprofloxacin (CIP), seeds failed to germinate in all except in CIP to which the bacteria was tested sensitive.

Table 3. Antibacterial activity of isolated bacterial strain against test bacterial agents.

\begin{tabular}{lc} 
Test bacterial agents & $\begin{array}{c}\text { Diameter of } \\
\text { inhibition } \\
\text { Zones }(\mathrm{mm})\end{array}$ \\
Klebsiella sp. & $27 \pm 0.75$ \\
E. coli & $19 \pm 1.0$ \\
\hline
\end{tabular}


The seed were not affected by the supernatant ( $24 \mathrm{hrs}$ old bacterial culture centrifuged at $8000 \mathrm{rpm}$ for 10 minutes) and their germination time showed no prominent difference from the control seeds.

\section{Discussion and Conclusions}

The farmers are still unaware of the soil micro-biota that plays a major role in influencing plant growth. Growth of a healthy crop is often credited to the compounds (manure and fertilizers) added to the soil, whereas growth of an unhealthy crop is linked to nutrient deficiency or some kind of insect related diseases. Lack of knowledge and less awareness leads to reduced crop productivity every year as the farmers keep on supplementing the soil with unnecessary formulations including biofertilizers. The present study focused on exploring the characteristic features (both positive and negative) of the isolated bacterial strain of $P$. aeruginosa. It was observed that the bacterial strain survive at $\mathrm{NaCl}$ concentration of $10 \%$ and produce a considerable amount of IAA up to $8 \% \mathrm{NaCl}$ concentration. It is able in producing siderophores, $\mathrm{HCN}$ and ammonia and solubilizing phosphate. It has a recommendable antagonistic activity against the three phytopathogenic fungi and two bacterial strains. At the same time it also has its negative effect over seeds of maize and wheat. The seeds treated with isolated strain failed to germinate which indicates that under normal conditions in nature this particular strain inhibits plants to continue their gene line. Also it may be the major reason behind the loss of crop productivity due to inability of seeds to germinate. ${ }^{27}$ It occurred that the cellular products of the strain did not have a negative impact over the seed germination from which it can be concluded that the deleterious nature of the strain is only viable up till the cells are able to infect and proliferate over seeds interfering with the seed germination mechanism. Its ability to sustain its growth under saline conditions, $\mathrm{HCN}$ and siderophore production and antibiotic resistance makes it a highly resistant strain and a potent inhibitor of other microbial agents. From this study we introduce a new bacterial strain of $P$. aeruginosa that possesses both deleterious as well as plant growth promoting characteristics.

\section{References}

1. Emori TG, Gaynes RP. An overview of nosocomial infections, including the role of the microbiology laboratory.
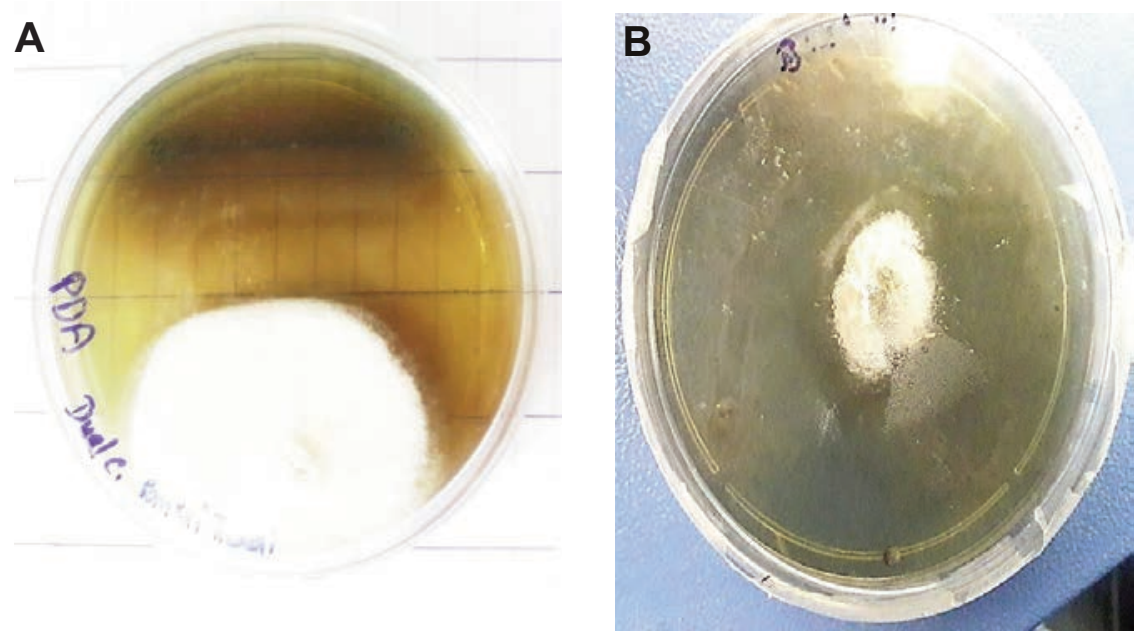

Figure 6. Bacterial antagonism against Fusarium solani: A) single streak method, B) double streak method.
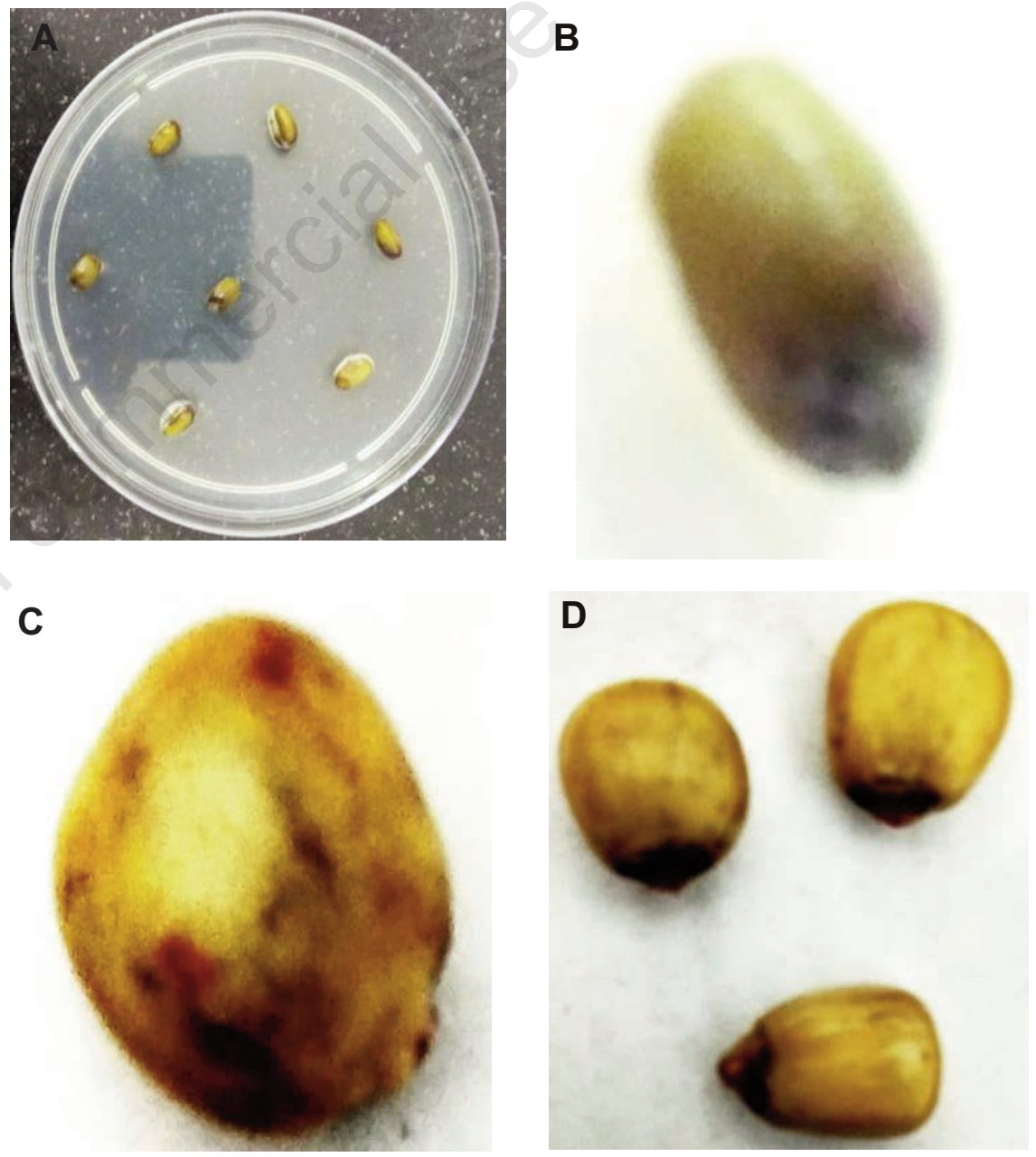

Figure 7. A) Inability of wheat seeds to germinate, B) seed showing bacterial growth, C) and $D$ ) showing maize grains after 12 days of sowing.

Clin Microbio Rev 1993;6:428-42. 2. Aloush V, Navon-Venezia S, Seigman- 
Table 4. Percentage growth inhibition in target microbial agents.

\begin{tabular}{lcc}
\hline Fungi tested against & Single streak method & \\
Aspergillus niger & $36.21 \%$ & $68.35 \%$ \\
Fusarium solani & $57.12 \%$ & $74.72 \%$ \\
\hline Curvularia lunata & $24.37 \%$ & $72.13 \%$ \\
\hline & & \\
Table 5. Plant growth promoting characteristics. & \\
Plant growth promoting abilities & Observations \\
Phosphate solubilization & Present \\
Zinc solubilization & Absent \\
\hline NH ${ }_{3}$ production & Present \\
HCN production & Present \\
\hline Siderophore production & Present \\
IAA production & Present up to 8\% NaCl concentration \\
\hline Antagonism against phytopathogens & Present \\
\hline
\end{tabular}

Igra $\mathrm{Y}$ et al. Multidrug-resistant Pseudomonas aeruginosa: risk factors and clinical impact. Antimicrob Agents Chemother 2006;50:43-8.

3. Kloepper JW, Lifshitz R, Zablotowicz RM. Free-living bacterial inocula for enhancing crop productity. Trends Biotechnol 1989;7:39-43.

4. Dobbelaere S, Vanderleyden J, Okon Y. Plant growth-promoting effects of diazotrophs in the rhizosphere. CRC Crit Rev Plant Sci 2003;22:107-49.

5. Glick BR. The enhancement of plant growth by free-living bacteria. Can J Microbiol 1995;41:109-17.

6. Chachalis D, Reddy KN. Factors affecting Campsis radicans seed germination and seedling emergence. Weed Sci 2000;48:212-6.

7. Taylorson RB. Environmental and chemical manipulation of weed seed dormancy. Rev Weed Sci 1987;3:13554.

8. Kennedy AC, Johnson BN, Stubbs TL. Host range of a deleterious Rhizobacterium for biological control of downy brome. Weed Sci Soc Am 2001;4):792-7.

9. Kolker II, Moroz AF, Bekbergenov $\mathrm{BM}$, et al. Selective media for isolating Pseudomonas aeruginosa. $\mathrm{Zh}$ Mikrobiol Epidemiol Immunobiol 1982;11:75-9.

10. Bartholomew JW, Mittwer T. The Gram stain. Bacteriol Rev 1952;16:1-29.

11. Facklam R, Elliott JA. Identification, classification, and clinical relevance of catalase-negative, gram-positive cocci, excluding the streptococci and enterococci. Clin Microbiol Rev 1995;8:479.

12. Garcia LSI, Henry D. Clinical Microbiology Procedures Handbook. American Society for Microbiology, 2004; Washington, DC: ASM Press, United States.

13. MacWilliams MP. Citrate Test Protocol. American Society for Microbiology, 2009.

14. Christensen WB. Urea decomposition as a means of differentiating Proteus and Paracolon cultures from each other and from Salmonella and Shigella types. J Bacteriol 1946;52:461-6.

15. Carbonnelle E, Mesquita C, Bille E, et al. MALDI-TOF mass spectrometry tools for bacterial identification in clinical microbiology laboratory. Clin Biochem 2011;44:104-9.

16. Fiebelkorn KR, Crawford SA, McElmeel ML, et al. Practical disk diffusion method for detection of inducible clindamycin resistance in Staphylococcus aureus and coagulasenegative Staphylococci. J Clin Microbiol 2003;41:4740-4.

17. Pikovskaya RI. Mobilization of phosphorus in soil in connection with the vital activity of some microbial species. Mikrobiologiya 1948;17:362-70.

18. Bunt JS, Rovira AD. Microbiological studies of some sub Antarctic soils. J Soil Sci 1955;6:119-28.

19. Cappuccino JG, Sherman N. Biochemical activities of microorganisms. Microbiology, a laboratory manual. The Benjamin Cummings Publishing Co., California, 1992.

20. Castric PA. Hydrogen cyanide, a secondary metabolite of Pseudomonas aeruginosa. Can J Microbiol 1975;21:613-8.

21. Schwyn B, Neilands JB. Universal chemical assay for the detection and determination of siderophores. Anal Biochem 1987;160:47-56.

22 Ehmann A. The Van Urk-Salkowski reagent-a sensitive and specific chromogenic reagent for silica gel thinlayer chromatographic detection and identification of indole derivatives. J Chromatogr 1977;132:267-76.

23. Farah A, Iqbal A, Mohd Saghir K. Indole Acetic acid production by the indigenous isolates of Azotobacter and Fluorescent Pseudomonas in the presence and absence of tryptophan. Turk J Biol 2005;29-34.

24. Heatley NG. A method for the assay of penicillin. Biochem J 1944;38:61-5.

25. Skidmore AM, Dickinson CH. Colony interactions and hyphal interference between Septoria Nodorum and phylloplane fungi. Trans Brit Mycol Soc 1976;66:57-64.

26. Rajput L. Imran A. Mubeen F, Hafeez F. Salt-Tolerant PGPR strain Planococcus rafietoensis promotes the growth and yield of wheat (Triticum aestivum L.) cultivated in soil. Pak J Bot 2013;45:1955-62.

27. Finch-Savage WE. Bassel GW. Seed vigour and crop establishment: extending performance beyond adaptation. J Exp Bot 2016;67:567-91. 